\title{
Correction: Equivalence of semistability of Picard, Mann, Krasnoselskij and Ishikawa iterations
}

Bahmann Yousefi', Akram Yadegarnejad ${ }^{1}$, Hassan Azadi Kenary² and Choonkil Park ${ }^{3 *}$

\section{"Correspondence:}

baak@hanyang.ac.kr

${ }^{3}$ Department of Mathematics,

Research Institute for Natural

Sciences, Hanyang University, Seoul,

133-791, Korea

Full list of author information is

available at the end of the article

\section{Correction}

In [1] the following author names were incorrectly spelt as Ali Yadegarnejad and Bahman Yousefi. Please note the correct names present in the above author list. The first affiliation has also been corrected; it was incorrectly written P.O. Box 19395-4697.

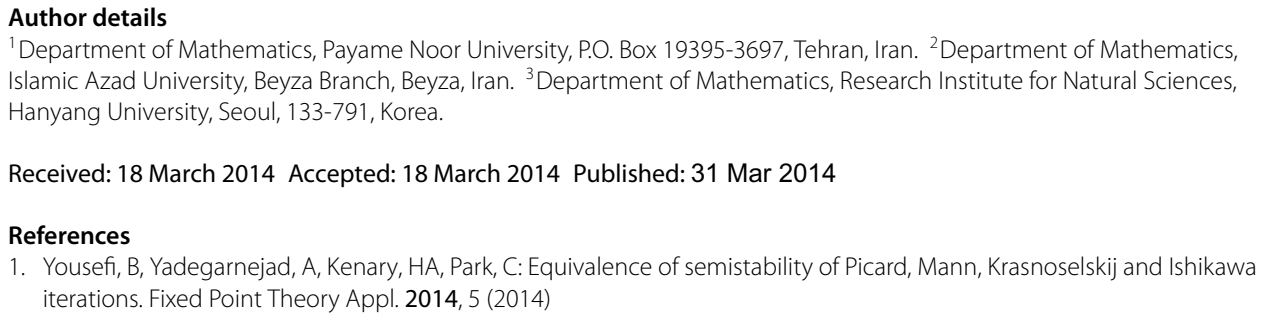

Received: 18 March 2014 Accepted: 18 March 2014 Published: 31 Mar 2014

References

1. Yousefi, B, Yadegarnejad, A, Kenary, HA, Park, C: Equivalence of semistability of Picard, Mann, Krasnoselskij and Ishikawa iterations. Fixed Point Theory Appl. 2014, 5 (2014)

10.1186/1687-1812-2014-84

Cite this article as: Yousefi et al.: Correction: Equivalence of semistability of Picard, Mann, Krasnoselskij and Ishikawa iterations. Fixed Point Theory and Applications 2014, 2014:84

\section{Springer}

02014 Yousefi et al: licensee Springer. This is an Open Access article distributed under the terms of the Creative Commons Attribution License (http://creativecommons.org/licenses/by/2.0), which permits unrestricted use, distribution, and reproduction in any medium, provided the original work is properly cited.
Submit your manuscript to a SpringerOpen ${ }^{\circ}$ journal and benefit from:

- Convenient online submission

- Rigorous peer review

- Immediate publication on acceptance

- Open access: articles freely available online

- High visibility within the field

- Retaining the copyright to your article

Submit your next manuscript at $>$ springeropen.com 